\title{
Technopreneurship and Enterprise Growth in Nigeria: An Exploration into the Latent Role of Microfinance Banks
}

\author{
A. Y. Dutse ${ }^{1}$, S. I. Ningi ${ }^{2}$, and S. Abubakar ${ }^{3}$ \\ 1. School of Management Technology, Abubakar Tafawa-Balewa University, PMB 0248, Bauchi-Nigeria \\ 2. School of Management Technology Abubakar Tafawa-Balewa University, Bauchi-Nigeria \\ 3. Bauchi Investment Corporation
}

\begin{abstract}
Blend of technology prowess and entrepreneurial skills are known to be the important drivers of enterprise growth in many nations. In Nigeria new policies, structures and strategies are being explored and formulated to help technology-based small and medium-sized enterprises grow and to offer a promising future for the country's businesses within the global market place. In the same vein, Central Bank of Nigeria recently intensified effort to further promote the development and expansion of Microfinance banking activities in the country with a view to availing Nigeria's entrepreneurs the opportunity to exploit economic benefits of such banks. This article explores the role microfinance banks can play in promoting technoprenuership derive and growth among micro, small and medium scale enterprises in Nigeria by employing Pearson Correlation to establish relationship between the variables and Multivariate Analysis of Variance to show causal effects. The coefficients results show strong positive association between the variables as well as significant causal effect between the predictor variable and the two criterion variables. Hence it is recommended that creating favourable financial conditions for entrepreneurs will hasten the development of technopreneural drive and subsequent enterprises growth in Nigeria
\end{abstract}

Keywords: Technopreneurship, Enterprise Growth, Microfinance in Nigeria

\section{Introduction}

The link between technology, entrepreneurship and the ensuing growth of Micro, Small and Medium Enterprises (MSMEs) in a given economy has long been accorded a prime place in business, management and economics sciences literature. Reflecting on globalization and how it has raised the importance of creative hightech and entrepreneurial skills; technopreneurship has become as an answer to unlock creativity and sustain long-run competitive advantage in the present world where economic issues have combined with increased competitiveness. Subsequently, this need to combine the quest and requirement for technology with all elements of entrepreneurship led to the development of the term "technopreneurship" which refers to new or prospective enterprises that is anchored on technology.

Nigeria as a developing nation has for long explored and formulated policy structures and strategies to promote technology-based MSMEs growth and to offer a promising future within the global marketplace. While the initiatives have been marked by some successes, there are also cases of outstanding challenges caused especially by unavailability of capital for entrepreneurs. This necessitated the need for economic planners to further explore other alternative avenues of promoting enterprise growth through the transformation and strengthening of the nation's banking industry as well as the introduction and promotion of the microfinance banking system aimed at building capacity in the nation's macro-economic activities. This research was conducted with the prime objective of contributing to the current body of knowledge on the matter by providing an insight on the potential role of microfinance banks in facilitating the growth of MSMEs activities in Nigeria.

The significance of this study is justified by the fact that MSMEs are globally acknowledged as important factors required for the socio-economic transformation of any nation. In the case of Nigeria, the MSME sector is strategically positioned to absorb up to $80 \%$ of jobs, improve per capita income, increase value addition to raw materials supply, improve export earnings and step up capacity utilisation in key industries [1]. Anchored on the above ground, this study was conducted to provide credible and reliable insights into the dynamics of the factors that may be responsible for the growth and development of the sector in Nigeria and by so doing it also covers the gap created by paucity of research output in this important area.

\section{Nigeria's Experience}

The history and development of technopreneurship in Nigeria is linked to the entrepreneurship development process. Prior to 1970 the role of government was not significant till 1986 after the introduction of Structural Adjustment Program (SAP) which was subsequently followed by the establishment of the Small Scale Industries Credit Guarantee Scheme (SSICS), National Directorate of Employment (NDE), National Open Apprenticeship Scheme (NOAS), Small and Medium Enterprise Development Agency of Nigeria (SMEDAN), 
as well as Centre for Entrepreneurship Development (CED), National Centre for Technology Incubation (NCTI). The process received a major boost with the introduction of privatization and commercialization decrees in 1988 - 1995 resulting in the emergence of business enterprises in the fields of agriculture, manufacturing, banking, mining, education, publishing, and information \& communication technology. This development provided the fertile ground needed for the emergence of micro, small and medium enterprises that are engaged in the production and provision of auxiliary products and services. The role of Government became much more apparent through the activities of SMEDAN by supporting and supervising entrepreneurship units while the Central bank of Nigeria provides financial assistance to entrepreneurs through the $10 \%$ fund contribution by commercial banks to the Small and Medium Enterprise Equity Investment Scheme (SMEEIS). As noted by Babajide, [2] "the scheme aimed at assisting the establishment of new, viable small and medium industries; thereby stimulating economic growth, and development of local technology, promoting indigenous entrepreneurship and generating employment".

The recent policy of government on Microfinance banks which was launched in 2005 through the central bank was actually aimed at providing additional source of funding and thus complementing the activities of the other agencies. The policy provided the regulatory and supervisory framework for addressing the problem of poor access to credit by small entrepreneurs who may not have access to customary bank credits. This aided in raising the level of access to financial services for large segment of the productive business units by enabling the MSMEs to secure credits and access other financial services. This development has prompted the expansion of entrepreneurial activities in a wide range of ventures like machines and tools fabrication; building and construction, plan and design services, material sourcing; agriculture, foodstuff, restaurant, fast food vending; ICT, internet services, mobile phone services, manufacturing and repairs of GSM accessories, Hotels, accommodation, resort and recreation, film and home video production; refuse collection, disposal, recycling etc [3].

\section{Literature Review}

Technoprenuership - The concept of technoprenuership is still new and is considered as a real source of economic power in today's knowledge-based as well as developing economies. A large body of the literature exists on the concept of entrepreneurship explaining variety of views of different scholars on the subject. The general consensus on the concept is that it reflects an entrepreneur who combines resources such as land, labour and capital to produce a product, make non-routine decisions, be aggressively competitive, technologically innovative and bear risks [4], [5], [6], [6], [7]. The term technoprenuership, in the context of this study is used to describe entrepreneurs who combine entrepreneurial skills with technology. They are characterised by [8], [9], [10] as "technology-based entrepreneurs", "technical entrepreneurs", "high technology entrepreneurs". The importance of technopreneurship can be seen in its high correlation with technology; it thus, can be a significant value driver of national competitive advantage.

Enterprise Growth - The suggestion that there is a strong and positive correlation between technopreneurship and the growth of enterprises has certainly been discussed in literature since the early works on entrepreneurship and economic development by Schumpeter [11]. Experts argue that an increase in the number of technopreneurs leads to an increase in enterprise growth which is also a direct result of their skills, and their tendency to innovate [12]. Their ability to generate enterprise growth in a particular economy is normally manifested in their innovative capability, as described in [12], by introducing new goods and services which are not familiar to consumers, new quality, new method of production, opening of a new market, and capture of a new source of supply of raw materials or other inputs. The obvious ability and willingness of entrepreneurs (who anchor their business thrust on technology) to practically perceive and create new business opportunities and decide to venture in to such opportunities in spite of the challenges of market uncertainties and other impediments, affect and ultimately renew the business activities, not only within their business units and industries, but also within the economy they are situated [13].

Microfinance Banks - Microfinance has been described as a form of financial development which primary aim is to alleviate poverty of the poor who are generally not served or are offered improper financial services [14]. Also part of the primary objective of their establishment is to provide financial services to entrepreneurs of MSMEs, which will subsequently improve the socio-economic condition and their income-generation activities. Hence the potential benefits of microfinance has accounted for its widespread adoption as a vital element in economic development and job creation as well as poverty reduction strategy [15]. Similarly, substantial literature exists which contains descriptions of the significance of relationship between the activities of microfinance banks and the development of technoprenuership leading to enterprise growth [16], [9], [13]. 


\subsection{Interlocking Relationship between Microfinance, technopreneurship and Enterprise Growth}

The occurrence of microfinance as a variable with a differing role, suggests a model consisting of three interlinked variables. This representation revolves around the links between entrepreneurs that use available technology on their own, in teams, within and outside existing organizations, to introduce their ideas in the market, new products or services, new methods, new operation styles by deciding on location, type of resources and other relevant institutions [12] like the microfinance banks. The culmination of these technopreneural initiatives in an aggregated form could result in general enterprises growth which, to a greater extent, can be measured in terms increase in competiveness, market share, quality, profitability, and innovation gained by the business units. In the model microfinance services availability are considered the important factor in influencing the dimension and extent of technopreneural initiatives vis-à-vis enterprise growth.

The influence is normally driven by their activities in provision of a wide range of financial services like saving accounts, loans, payment services and insurances for people with no regular access to financial services through traditional financial institutions [16]. Similarly to the views of [17] microfinance in the context of this discuss is the availability of access to financial services such as small sized credit to enterprises that may not have collateral, financial records or credit history but have established business and uses some form of technology. As illustrated in figure 1 entrepreneur's ability to hinge his business on technology is a dependent factor in the model because the ability of such enterprises to acquire the technology is driven by their financial capability, and microfinance banks can be important sources of these funds.

Hence, microfinance occupies a central position in the success of technopreneurs whose activities would result in generating growth within the locus of businesses units. As highlighted by [18] the role of microfinance banks in Nigeria can facilitate the growth of technopreneurs by serving as a relatively cheap source of funds to small scale businesses, providing access to financial guaranty for loans that is easily accessible to small scale businesses, reinforcing responsibility, repayment discipline and reinforcing the viability of operators of small scale businesses. Several other research arguments have suggested that the intensity of microcredit available to entrepreneurs in a particular setting accounts for the relative level of enterprise growth. Investment-generated innovativeness is associated with lower transaction costs and, therefore, greater efficiency, competiveness, market growth as well as increased earnings. Consequently, absences of funds yield little room for opportunities in terms of increased innovative activities.

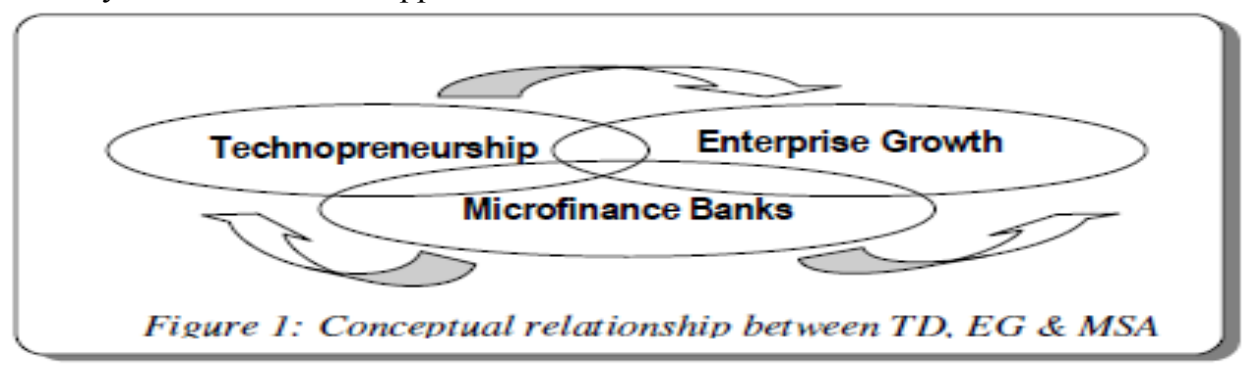

In this context, it is proposed (see figure 1) that within general business environment in Nigeria, technopreneurs would serve as agents who would access capital from microfinance banks, acquire technology and combine them with other factors of production to create successful business ventures. Expectedly, given the abundant natural resource and cheap labour in Nigeria, the technopreneurs will be able to help build a significant cluster of viable ideas and business schemes in order to develop a number of excellent enterprises in Nigeria. Consequent on receiving financial services and advices from the microfinance banks, the technopreneurs will be able to manifest characteristics such as product and process innovativeness, high growth rate, technology adoption, and high market growth rate.

This could contribute significantly to the business as well as economic growth through value addition, wealth creation and job opportunities [19]. Based on the designed framework in figure 1, the hypothesised model is fairly simple with MSA as the core elements (the Predictive or independent variable) would result in the development of technopreneural drive among entrepreneurs as well as facilitating the growth of MSMEs (the criterion or dependent variables). As shown in figure 2, one factor - Microfinance Service Availability (MSA) was used to measure the dependent variables: Technopreneural Drive (TD) and Enterprise Growth (EG). Based on that, the following hypothesis had been formulated and tested:-

Hypothesis 1 - There is strong positive relationship between Microfinance services availability, technopreneural growth and growth of enterprises in Nigeria

Hypothesis 2 - The growth of technoprenuership drive and MSMEs significantly depend on the availability and accessibility of Microfinance services in Nigeria. 


\subsection{Population and Sampling Procedures}

\section{Methodology}

The Small and Medium Enterprises Development Agency of Nigeria (SMEDAN) and National Bureau of Statistics' Survey Report [1] provided the starting point for the design of the methodology employed in determining the population and sample size for this study. The SMEDAN report (the first of its kind) provides credible and reliable Micro, Small \& Medium scale Enterprises (MSMEs) database on the number and structure of MSMEs operatives in Nigeria on geo-political and sectoral basis. The report shows that there are 22,918 SMEs and 172,617,53 micro businesses, thereby making a total population of 17,284,671 MSMEs operating in Nigeria during the period under review. Consequently, in order to determine the sample size, the approximation procedure provided in [20] was used and a working sample size of 400 was drawn. Accordingly, a multi-stage sampling technique known as Probability Proportional to Size (PPS) Cluster Sampling was used as the sampling procedure for clustering the MSMEs in to six geo-political zones of the country and apportioning equal number of states to serve as survey clusters; then randomly selecting respondent MSMEs as influenced by their concentration in a cluster as similarly done in [21]. Table 1 provides the details of the sample clusters with five states in each cluster.

Table 1 Distribution of Clustered Sampled MSMEs by Zones

\begin{tabular}{llcc}
\hline \multicolumn{1}{c}{ Zones } & \multicolumn{1}{c}{ States } & $\begin{array}{c}\text { Number of } \\
\text { selected states } \\
\text { (Clusters) }\end{array}$ & $\begin{array}{c}\text { Sampled } \\
\text { MSMEs by } \\
\text { Zone }\end{array}$ \\
\hline North-Central & Benue, Kogi, Niger, Plateau, \& Abuja (FCT). & 5 & $68(17.00 \%)$ \\
North-East & Adamawa, Bauchi, Gombe, Taraba and Yobe & 5 & $57(14.25 \%)$ \\
North-West & Kaduna, Kano, Katsina, Kebbi, Sokoto & 5 & $82(20.50 \%)$ \\
South-East & Abia, Anambra, Ebonyi, Enugu, and Imo & 5 & $50(12.50 \%)$ \\
South-South & Akwa-Ibom, Bayelsa, Cross-River, Edo \& Rivers & 5 & $67(16.75 \%)$ \\
South-West & Lagos, Ogun, Ondo, Osun \& Oyo & 5 & $76(19.00 \%)$ \\
Total & & $\mathbf{3 0}$ & $\mathbf{4 0 0}(\mathbf{1 0 0 \% )}$ \\
\hline
\end{tabular}

Thereafter, from the 400 questionnaires distributed, a total of 338 were retrieved out of which 333 were found to be valid and useful while 62 questionnaires were not returned at all. The valid questionnaires constitute 83\% responses rate as shown in Table 2. These MSMEs provided responses on the level of investment in technology and usage in their business operations, levels of availability and access to microfinance services as well as the corresponding level of improvement in various aspects of their businesses. Albeit the valid questionnaires size of 333 was less than the desired size (399) by almost 17\%, it however, satisfied the standard size desirable for analysis of continuous data as recommended by [22] that to use correlation and multiple regression analysis, the ratio of observations to independent variables should not fall below five (5).

Table 2 Distribution and Retrieval of Questionnaires

\begin{tabular}{llcc}
\hline SN & \multicolumn{1}{c}{ Description } & \multicolumn{2}{c}{ Response Rate } \\
\hline 1 & Total Number of Questionnaires Distributed & 400 & $100 \%$ \\
2 & Desired Sample size (respondent firms) & 399 & $99.7 \%$ \\
3 & Total Number of Questionnaires Returned & 338 & $85 \%$ \\
4 & Total Number of Questionnaires not Returned & 62 & $16 \%$ \\
5 & Total Number of Questionnaires that are invalid & 5 & $1.3 \%$ \\
6 & Total Number of Questionnaires that are Valid & 333 & $83 \%$ \\
\hline
\end{tabular}

They further argue that if this minimum is not followed, the risk of over-fitting of results to specific sample exists, and would therefore be deficient in generalization. By implication a minimum of 15 (3 independent variables $x$ 5) respondents were required for this study.

\subsection{Data Screening, Scale Reliability and Normality Measurements}

MSMEs provided responses on a five-point technology usage estimation scale with values ranging from a minimum of 1 and a maximum of 5 indicating approximation of the level of technology adoption and usage, levels of access to microfinance services and levels increase in business performance. By so doing the responses were scaled in the following patterns: - 1 represents Very Low; 2 represents Low; 3 represents Moderate; 4 represents High; 5 represents Very High level of Technopreneurship drive. While for availability and access to microfinance services, 1 signifies Very Low; 2, Low; 3, Moderate; 4, High; 5, Very High levels. Similarly, in measuring the levels of improvement in business performance, 1 represents Very Low; 2 represents Low; 3 represents Moderate; 4 represents High; 5 represents Very High levels. The questionnaire was segmented in to three parts comprising constructs measuring TD, MSA and EG. As with the other analyses, SPSS was used in the Reliability test on the measurement scale by calculating the alpha coefficients guided by 
the positions of [23]. Accordingly, the three constructs exhibit highly reliable Cronbach's alpha values based on standardized items and other statistics as demonstrated in Table 3 . The highly reliable coefficients connote that the data generated by the instrument is good and fit for generalization of conclusions on the research findings.

Table 3 Scale and Reliability Test Statistics

\begin{tabular}{lccccc}
\hline \multicolumn{1}{c}{ Construct } & $\begin{array}{c}\text { Cronbach's } \\
\text { Alpha }\end{array}$ & Mean & Variance & $\begin{array}{c}\text { Std. } \\
\text { Deviation }\end{array}$ & $\begin{array}{c}\text { No. of } \\
\text { Questionnaire Items }\end{array}$ \\
\hline Technopreneurship Drive (TD) & 0.927 & 31.58 & 85.238 & 9.232 & 10 \\
Microfinance Service Accessibility (MS) & 0.962 & 29.76 & 151.864 & 12.323 & 10 \\
Enterprise Growth (EG) & 0.935 & 36.09 & 80.723 & 8.985 & 10 \\
\hline
\end{tabular}

i. Technopreneurship Drive (alpha coefficient $=0.927$ ) - measured by the MSMEs general use of technology in their businesses, use of simple machines, computerization of operations, adoption and usage of mobile technologies, use of other electronic media, acquisition and use of satellite and other communication media, use of office technologies, software and other components.

ii. Microfinance Services Accessibility (alpha coefficient $=0.962$ ) - measured by availability of microfinance banks in the business locality, rate of patronage, ease of access to soft loans and microcredit, access to financial advices, availability of micro-insurance services, ease and availability of deposits, payments and savings facilities, level of absence of collateral, good credit history and interest on loans.

iii. Enterprise growth (alpha coefficient $=0.935$ ) - signified by levels of increases in output, sales, product quality, product and process innovation, new methods, new market entrance, capture of new sources of supply of raw materials and other inputs, increase in level of effectiveness, work efficiency, quality of output and overall reduction in costs.

As for the test of normality of the data, figure 2 demonstrates the absence of outliers in the data, while figure 3 displays the graphical distributions of random variables' differences between empirical distribution and a theoretical distribution which emerged to be fairly normal.
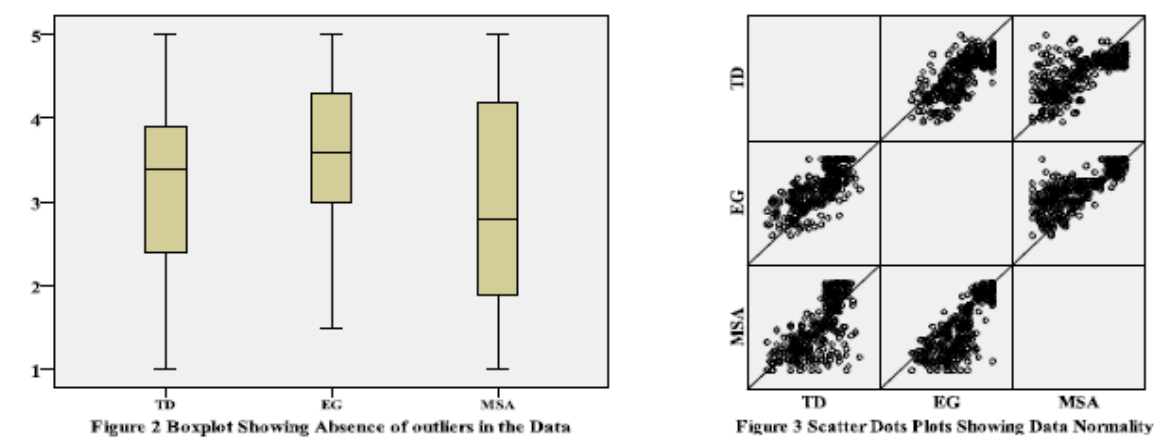

\section{Results And Discussions}

The study reveals the outcome based on the information provided by the MSMEs on the influence of availability of microfinance services on the development of entrepreneurial drive and enterprise growth. The analyses process involves three stages; the first stage analysed the frequency distribution statistics of firms in terms of type, location, number of years in operation as well as size. The second stage adopted the use of multiple correlations to establish relationships between the three variables and to further strengthen the evidence of the normality of the data while the third stage used Multivariate Analysis of Variances (MANOVA) to measure causal effect of MSA on TD and BD. This is done in a composite manner because the model comprises of one predictor variable and two criterion variables. Accordingly, Pearson correlation and MANOVA confidents were used to test the hypothesized models. The decision to adopt MANOVA is because of the fact that it is essentially examining the effect of a single independent variable (MSA) on the composite dependent variables (TD \& BD). The advantage of the MANOVA over other methods is that it is capable of keeping the overall probability of a Type I error fixed at the chosen level of 0.05 [23].

In line with procedure adopted during the analyses, the results are presented in two phases; firstly, descriptive analyses of the frequency distribution of the firms by type, location, years of operation and size of business, while the second part provides the outcome of inferential statistics used for hypotheses testing. Hence, as shown in Table 4 the descriptive analysis on the general business information, examines MSMEs under 11 business types. Out of the 333 sampled MSMEs up to $79(23.7 \%)$ are in the ICT business, this is followed by businesses in the agriculture sector where there are 61 MSMEs business firms representing $18.3 \%$. 
Business in the food and trade services represent $47(14.1 \%)$ each of the sampled firms. Businesses in the sanitation and tourism sub sectors represent $6(1.8 \%)$ each of the sampled business firms, while the health sub sector has only 5 firms representing (1.5\%) of the firms in the sample. MSMEs Business in the manufacturing sub sector accounted for 23 firms representing (6.9\%), transport sub sector closely follows the manufacturing sub sector by contributing 21 firms representing $(6.3 \%)$ of the sample, while education and petroleum sub sectors have 19 (5.7\%) MSMEs business firms each of the sample size. In terms of location, North West accounted for 71 representing $21.3 \%$ of the MSMEs in the sample, the south west is second with 61 (18.3\%) of the MSMEs in the sample. North central closely followed with 59 business firms (17.7\%), while the South-south is represented by 56 business firms $(16.8 \%)$ in the sample. $50(15.0 \%)$ of the business firms in the sample are located South east, with only $36(10.8 \%)$ of the business firms in the sample located in the North east of the country.

Table 4 Frequency Distribution Statistics of MSMEs

\begin{tabular}{lclcllll}
\hline Bus Type & $\begin{array}{c}\text { Frequency } \\
(\%)\end{array}$ & Location & $\begin{array}{c}\text { Frequency } \\
(\%)\end{array}$ & Years In Operation & $\begin{array}{c}\text { Frequency } \\
(\%)\end{array}$ & $\begin{array}{c}\text { Bus Size } \\
(\%)\end{array}$ \\
\hline Agriculture & $61(18.3)$ & North-Central & $59(17.7)$ & Less than 1 Year & $19(5.7)$ & Micro & $157(47.1)$ \\
Trade & $47(14.1)$ & North-East & $36(10.8)$ & $1-5$ Years & $114(34.2)$ & Small & $104(31.2)$ \\
Sanitation & $6(1.8)$ & North-West & $71(21.3)$ & $6-10$ Years & $128(38.4)$ & Medium & $72(21.6)$ \\
Manufacture & $23(6.9)$ & South-East & $50(15.0)$ & $11-15$ Years & $61(18.3)$ & Total & $333(100)$ \\
Petroleum & $19(5.7)$ & South-South & $56(16.8)$ & Above 15 Years & $11(3.3)$ & $33(100)$ \\
Food & $47(14.1)$ & South-West & $61(18.3)$ & Total & & & \\
Transport & $21(6.3)$ & Total & $333(100)$ & & & & \\
ICT & $79(23.7)$ & & & & & & \\
Education & $19(5.7)$ & & & & & & \\
Health & $5(1.5)$ & & & & & & \\
Tourism & $6(1.8)$ & & & & & \\
Total & $333(100)$ & & & & & \\
\hline
\end{tabular}

Experience of the MSMEs as measured by their years in operation indicates that $128(38.4 \%)$ of the enterprises in the sample have been in business for the fast 6-10 years. Enterprises with 1-5 years experience in operation are 114 in number representing 34.2\% of the MSMEs in the sample. MSMEs having up to 11-15 years of operation experience are only $61(18.3 \%)$ of the sampled enterprises. Only $11(3.3 \%)$ of the firms have more than $15 \%$ years experience in operation. 19 of the MSMEs representing $5.7 \%$ are just starting as they have less than a year experience in operation. The sizes of the enterprises under study indicates that almost half of them $157(47.1 \%)$ are micro in nature, $104(31.2 \%)$ are small and only $72(21.6 \%)$ are medium size enterprises

\subsection{Test of Hypothesis 1}

The second part of the analyses provides coefficients of Pearson correlation which is a relational statistical technique used to measure the strength of some relationships between the independent and dependent variables. Analysis of the correlation matrix in Table 5 indicates that many of the observed relationships between MSA, TD and EG variables are all positive and strong so also in-between all the variables. For instance between MSA and EG is $r=0.795$ is the strongest (i.e. between independent and dependent) followed by TD $r=$ 0.675; while between TD and EG r $=0.722$ also strong. The relationship between MSA and TD is the weakest relationship in the matrix signifying that inter-variables association in the model is significant and strong.

Table 5 Correlations Coefficients for Establishing Variables' Relationships

\begin{tabular}{|c|c|c|c|c|}
\hline & & MSA & TD & EG \\
\hline MSA & Pearson Correlation & 1 & & \\
\hline $\mathrm{TD}$ & Pearson Correlation & $0.675^{* *}$ & 1 & \\
\hline EG & Pearson Correlation & $0.796^{* *}$ & $0.722^{* *}$ & 1 \\
\hline \multicolumn{2}{|c|}{ Sig. (2-tailed) } & 0.000 & 0.000 & 0.000 \\
\hline \multicolumn{2}{|l|}{$\mathrm{N}$} & 333 & 333 & 333 \\
\hline
\end{tabular}

Consequently, hypothesis 1 is accepted. By implication, it signifies that if Microfinance services would be made available and accessible, not only will there be increase in technopreneural drive but also the growth of MSMEs in Nigeria, since each of the factors reinforces of the other. 


\subsection{Test of Hypothesis 2}

As earlier mentioned, in testing the second hypothesis, multivariate analysis of variance was conducted in a composite manner to validate the existence and establish the strength of causal relationship among the variables as outlined in the hypothesis. In doing so the single predictive covariate MSA was employed with TD \& EG as the dependent variables. Hence, within the multivariate coefficients in Table 6, Wilks' Lambda test statistic is significant, which indicate that overall there is a significant effect of Microfinance service availability and accessibility on both dependent variables signified by $F(2,330)=312.303, p<0.05$; Wilks' lambda $=0.346$.

Furthermore, Table 7 shows the results of tests of between-subjects effects which allow the examination of the dependent variables individually. It is obvious from the table that for the dependent variable TD there is a significant effect of MSA, $F(1,331)=8.803 ; p<0.05$. So also for dependent variable EG the effect of MSA is significant, $F(1,331)=571.169 ; p<0.05$.

Table 6 Multivariate Tests Coefficients for Establishing Causal Relationships

\begin{tabular}{llccccc}
\hline \multicolumn{1}{c}{ Effect } & Value & $\mathrm{F}$ & Hypothesis df & Error df & Sig. \\
\hline \multirow{6}{*}{ Pillai's Trace } & .659 & $318.269^{\mathrm{a}}$ & 2.000 & 330.000 & 0.000 \\
& Wilks' Lambda & .341 & $318.269^{\mathrm{a}}$ & 2.000 & 330.000 & 0.000 \\
& Hotelling's Trace & 1.929 & $318.269^{\mathrm{a}}$ & 2.000 & 330.000 & 0.000 \\
& Roy's Largest Root & 1.929 & $318.269^{\mathrm{a}}$ & 2.000 & 330.000 & 0.000 \\
& Pillai's Trace & .654 & $312.303^{\mathrm{a}}$ & 2.000 & 330.000 & 0.000 \\
& Wilks' Lambda & .346 & $312.303^{\mathrm{a}}$ & 2.000 & 330.000 & 0.000 \\
& Hotelling's Trace & 1.893 & $312.303^{\mathrm{a}}$ & 2.000 & 330.000 & 0.000 \\
& Roy's Largest Root & 1.893 & $312.303^{\mathrm{a}}$ & 2.000 & 330.000 & 0.000 \\
\hline
\end{tabular}

a. Exact statistic

b. Design: + MSA

The Sums of Squares in the table also give the measure of the variability in the scores due to the particular factor which serves as a source of variability. The Adjusted R Squared values under the table indicate the amount of variation in each dependent variable that can be accounted for by the independent factor. For instance the Adjusted R Squared for TD is 0.454 , which shows that the MSA account for $45.4 \%$ of the variation in TD, while the Adjusted R squared for EG is 0.632 showing that MSA account for $63.2 \%$ of the variation in EG. It should be noted that test for homogeneity is ignored because of the fact that there are no between-subjects factors in the model.

The outcome of these parametric analyses show that the linear combination of the two dependent factors being significantly related to changes in independent factors thus the hypothesis 2 is accepted. Hence, the model emerges to be very useful for making predictions especially in the case of TD since the value of adjusted $R^{2}$ is closer to 1 . Hence at $(0.05) 5 \%$ significance and $95 \%$ confidence levels, the data provide sufficient evidence to conclude that availability and accessibility of microfinance services is useful as a predictor of the development of technopreneural drive and growth of micro, small and medium scale enterprises in Nigeria.

Table 7 Tests of Between-Subjects Effects

\begin{tabular}{|c|c|c|c|c|c|c|}
\hline & Dependent Variable & $\begin{array}{c}\text { Type III Sum of } \\
\text { Squares }\end{array}$ & $\mathrm{df}$ & Mean Square & $\mathrm{F}$ & Sig. \\
\hline \multirow[t]{4}{*}{ Corrected Model } & TD & $128.913^{\mathrm{a}}$ & 1 & 128.913 & 276.938 & 0.000 \\
\hline & EG & $169.673^{b}$ & 1 & 169.673 & 571.169 & 0.000 \\
\hline & TD & 132.867 & 1 & 132.867 & 285.432 & 0.000 \\
\hline & EG & 172.367 & 1 & 172.367 & 580.236 & 0.000 \\
\hline \multirow[t]{2}{*}{ MSA } & TD & 128.913 & 1 & 128.913 & 276.938 & 0.000 \\
\hline & EG & 169.673 & 1 & 169.673 & 571.169 & 0.000 \\
\hline \multirow[t]{2}{*}{ Error } & TD & 154.079 & 331 & .465 & & \\
\hline & EG & 98.328 & 331 & .297 & & \\
\hline \multirow[t]{2}{*}{ Total } & TD & 3603.900 & 333 & & & \\
\hline & EG & 4606.030 & 333 & & & \\
\hline \multirow[t]{2}{*}{ Corrected Total } & $\mathrm{TD}$ & 282.991 & 332 & & & \\
\hline & EG & 268.001 & 332 & & & \\
\hline
\end{tabular}




\section{Conclusion}

The study identified and reasserts the position of microfinance as a central policy and research issue in the development of technopreneurship and enterprise growth among MSMEs in Nigeria. It becomes obvious that functions provided by microfinance banks are important to the development of Nigeria's MSMEs because of their potentiality in enabling the technopreneurs generate high value jobs, spawn export activity, and hasten value for new technology anchored enterprise, especially ICT business which is capable of generate new jobs, new knowledge, and improving productivity and at the same time enlarging and sustaining Nigeria's entrepreneurial base. With these potentials, the desired output such as to improve national productivity and competitiveness will be achieved.

\section{References}

[1] SMEDAN (2010) Survey Report on Micro, Small and Medium Enterprises in Nigeria; Small and Medium Enterprises Development Agency of Nigeria Report, (Online Resource) Retrieved from on 20/2/12

[2] Babajide, A., (2012) Effects of Microfinance on Micro and Small Enterprises (MSES) Growth in Nigeria Asian Economic and Financial Review, 2(3), pp. 463-477.

[3] Shola, E. S., (2012) Entrepreneurship in Innovation, Phenomena Growth of Enterprises and Industrial Organisations in Nigeria, online resource, retrieved from http://www.scribd.com/doc/39258972/Entrepreneurship-in-Innovation on 23/1/2013

[4] Miller, D. (1983) The Correlates of Entrepreneurship in Three Types of Firms, Management Science, 29 , (7) 770-791.

[5] Covin, J. G., and Slevin, D. P. (1989) Strategic management of small firms in hostile and benign environments, Strategic Management Journal, 10: 75-87.

[6] Covin J.G. and Covin, T.J. (1990) Competitive Aggressiveness, Environmental Context and Small Firm Performance, Entrepreneurship Theory and Practice 14(4):35-50

[7] Lumpkin, G. T., and Dess, G. G. (2001) Linking Two Dimensions of Entrepreneurial Orientation to Firm Performance: The Moderating Role of Environment and Industry Life Cycle, Journal of Business Venturing, 16(5), 429-451.

[8] Jusoh, M. A. and Abdul Halim H. (undated) Role of Technopreneurs in Malaysian Economy, retrieved from http://www.jgbm.org/page/1\%20Mohd\%20Abdullah\%20Jusoh.pdf, on 16/2/13

[9] Egge, K., Tan, W., and Mohamed, O. (2003) Boosting Technopreneurship through Business Plan Contests: Malaysia's venture 2001 \& 2002 competitions, Hawaii International Conference on Business: June 18-20, 2003.

[10] Nwaobi, G. C. (2012) Business Entrepreneurship (Technopreneurship): Evolution and Practice, online Resource, Retrieved from SSRN: http://dx.doi.org/10.2139/ssrn.2044854 on 25/6/2013

[11] Schumpeter, J.A. (1911) The Theory of Economic Development. An Inquiry into Profits, Capital, Credit, Interest, and the Business Cycle, Oxford: Oxford University Press (1963 (1934).

[12] Dejardin, M. (2000) Entrepreneurship and Economic Growth: An Obvious Conjunction?, CREW, Faculty of Economics and Social Sciences, University of Namur. Retrieved from http://www.spea.indiana.edu/ids/pdfholder/IDSissn00-8.pdf, on 15/2/2013

[13] Alvarez, S. A., and Barney, J. B. (2007) Discovery and Creation: Alternative Theories of Entrepreneurial Action. Strategic Entrepreneurship Journal, 1(1-2), 11-26.

[14] CBN (2005) Central Bank of Nigeria Annual Report \& Statement of Accounts.

[15] Nwigwe, C. A., Omonona. B. T. and Okoruwa, V. O. (2012) Microfinance and Poverty Reduction in Nigeria: A Critical Assessment Australian Journal of Business and Management Research Vol.2 No.04 [33-40]

[16] Pretes, M., (2002) Microequity and Microfinance. World Dev., 30: 1341-1353.

[17] Schreiner, M. and Colombet,H.H. (2001) From Urban to Rural: Lessons for Microfinance from Argentina. Dev. Policy Rev., 19: 339-354.

[18] Edafiaje, A. L. (2011) Impact Assessment of the Role of Microfinance Banks in Financing Small Scale Enterprises in Delta State, Nigeria, International Journal of Economic Development Research and Investment Vol 2 No. 3, p. $109-114$.

[19] Sung, T. K., Gibson, D.V., Kang B.S. (2003) Characteristics of Technology Transfer in Business Ventures: The Case of Daejon, Korea. Technological Forecasting and Social Change, 70, $449-466$.

[20] Israel, G. D. (1992) Sampling: The Evidence of Extension Program Impact. Program Evaluation and Organizational Development, IFAS, University of Florida; PEOD-5, October; Retrieved from http://edis.ifas.ufl.edu/pdffiles/PD/PD00500.pdf 3/6/2011

[21] Dutse, A. Y. (2012) Technological Capabilities and FDI-related Spillover: Evidence from Manufacturing Industries in Nigeria. American International Journal of Contemporary Research, 2(8):201-212. Available online at http://www.aijcrnet.com/journals/Vol_2_No_8_August_2012/20.pdf

[22] Hair, J. F., Anderson, R. E., Tatham, R. L., and Black, W. C. (1995) Multivariate Data Analysis. Prentice-Hall, Upper Saddle River, N.J.

[23] Hinton, P. R., Brownlow, C., McMurray, I., and Cozens, B. (2004) SPSS Explained. Published by Routledge, 27 Church Road, Hove, East Sussex, BN3 2FA 